\title{
Plant hosts of the phytoplasmas and rickettsia-like-organisms associated with strawberry lethal yellows and green petal diseases
}

\author{
Claire Streten $^{\mathrm{A}, \mathrm{D}}$, Mark E. Herrington ${ }^{\mathrm{B}}$, Don G. Hutton ${ }^{\mathrm{B}}$, Denis M. Persley ${ }^{\mathrm{C}}$, Geoff K. Waite ${ }^{\mathrm{B}}$ \\ and Karen S. Gibb ${ }^{\mathrm{A}}$ \\ ${ }^{A}$ Charles Darwin University, Darwin, NT 0909, Australia. \\ ${ }^{B}$ Department of Primary Industries and Fisheries, Horticulture and Forestry Science, Maroochy Research Station, \\ Nambour, Qld 4560, Australia. \\ ${ }^{\mathrm{C}}$ Department of Primary Industries and Fisheries, Horticulture and Forestry Science, 80 Meiers Road, \\ Indooroopilly, Qld 4068, Australia. \\ DCorresponding author. Email: claire.streten@cdu.edu.au
}

\begin{abstract}
Candidatus Phytoplasma australiense ( $\mathrm{Ca}$. P. australiense) is associated with the plant diseases strawberry lethal yellows (SLY), strawberry green petal (SGP), papaya dieback (PDB), Australian grapevine yellows (AGY) and Phormium yellow leaf (PYL; New Zealand). Strawberry lethal yellows disease is also associated with a rickettsia-like-organism (RLO) or infrequently with the tomato big bud (TBB) phytoplasma, the latter being associated with a wide range of plant diseases throughout Australia. In contrast, the RLO has been identified only in association with SLY disease, and $C a$. P. australiense has been detected only in a limited number of plant host species. The aim of this study was to identify plant hosts that are possible reservoirs of $\mathrm{Ca}$. P. australiense and the SLY RLO. Thirty-one plant species from south-east Queensland were observed with disease between 2001 and 2003 and, of these, 18 species tested positive using phytoplasma-specific primers. The RLO was detected in diseased Jacksonia scoparia and Modiola caroliniana samples collected at Stanthorpe. The TBB phytoplasma was detected in 16 different plant species and $\mathrm{Ca}$. P. australiense Australian grapevine yellows strain was detected in six species. The TBB phytoplasma was detected in plants collected at Nambour, Stanthorpe, Warwick and Brisbane. Ca. P. australiense was detected in plants collected at Nambour, Stanthorpe, Gatton and Allora. All four phytoplasmas were detected in diseased Gomphocarpus physocarpus plants collected at Toowoomba, Allora, Nambour and Gatton. These results indicated that the vector(s) of $\mathrm{Ca}$. P. australiense are distributed throughout south-east Queensland and the diversity of phytoplasmas detected in G. physocarpus suggests it is a feeding source for phytoplasma insect vectors or it has a broad susceptibility to a range of phytoplasmas.
\end{abstract}

Additional keyword: Candidatus Phytoplasma australiense.

\section{Introduction}

The tomato big bud (TBB) phytoplasma is infrequently detected in strawberry plants with lethal yellows (SLY) disease while Candidatus Phytoplasma australiense (Ca. P. australiense; Davis et al. 1997) is consistently associated with SLY disease (Padovan et al. 1998; Padovan et al. 2000b). In Australia, Ca. P. australiense is also associated with the diseases strawberry green petal (SGP) (Padovan et al. 2000b), papaya dieback (PDB; Gibb et al. 1996; Liu etal. 1996), Australian grapevine yellows (AGY; Padovan etal. 1996) and mung bean witches' broom (MBWB; Schneider et al. 1999). More recently,
$C a$. P. australiense has been implicated as a causal agent of pumpkin yellow leaf curl (PYLC; Streten et al. 2005a) and periwinkle phyllody (Davis et al. 2003). Ca. P. australiense is also associated with plant diseases in New Zealand including strawberry lethal yellows (SLY; Andersen et al. 1998), Phormium yellow leaf (PYL; Liefting et al. 1998), Cordyline australis (cabbage tree) sudden decline (CSD; Andersen et al. 2001) and Coprosma lethal decline (CLD; Andersen et al. 2001).

Although $\mathrm{Ca}$. P. australiense has been consistently associated with a range of crop species, only a few non-crop host species have been identified during phytoplasma disease 
surveys in Australia (Davis et al. 1997, 2003; Schneider et al. 1999). The plant host range of a phytoplasma generally reflects the number of natural vector species that are capable of transmitting the organism and their feeding behaviour (Lee et al. 2000). Results to date suggest that the vector of $\mathrm{Ca}$. P. australiense has a narrow host range or a limited number of species are susceptible to this phytoplasma. In Australia, no vectors have been identified for $C a$. P. australiense whereas in New Zealand, the planthopper, Oliarus atkinsoni transmits this phytoplasma (Boyce and Newhook 1953; Liefting et al. 1997). O. atkinsoni is a monophagous species that feeds on Phormium sp. and is essentially limited to New Zealand (Liefting et al. 1998; Andersen et al. 2001), which means that it is unlikely to transmit $\mathrm{Ca}$. P. australiense in Australia. Identification of possible alternative hosts of $\mathrm{Ca}$. P. australiense may provide insight into the identity of its vectors in Australia. Furthermore, the detection of phytoplasmas in plants in the vicinity of strawberry farms would implicate these plant species as possible reservoirs of $C a$. P. australiense when strawberry plants are not being grown in the field.

In contrast to $C a$. P. australiense, the TBB phytoplasma has a wide host range including native and introduced plant species (Davis et al. 1997; Schneider et al. 1999; Padovan and Gibb 2001; Davis et al. 2003). These TBB phytoplasma-associated diseases occur throughout Australia (Davis et al. 1997, 2003; Schneider et al. 1999; Padovan and Gibb 2001). The TBB phytoplasma has provisionally been assigned the Candidate species name, Candidatus Phytoplasma australasia (White et al. 1998). The wide host range of the TBB phytoplasma possibly reflects the feeding habits of its insect vector, the common brown leafhopper, Orosius argentatus, which is widely distributed throughout Australia (Hill 1943).

A rickettsia-like-organism (RLO) is also associated with SLY disease (Greber and Gowanlock 1979). Little is known about this RLO, as until recently there was no diagnostic test. The development of a PCR diagnostic test, which amplifies the flavoprotein subunit succinate dehydrogenase $(s d h A)$ gene of the SLY RLO (Streten et al. 2005b) and the papaya bunchy top (PBT) RLO, has facilitated the identification of other hosts and possible vectors for this organism. The only known vector of an RLO is the leafhopper, Empoasca papayae, which transmits the PBT RLO (Davis et al. 1998). The identification of alternative hosts for the SLY RLO may indicate its host range and provide a focus for subsequent vector studies.

This study aimed to identify other host plants of $\mathrm{Ca}$. P. australiense by conducting disease surveys near strawberry farms where SLY disease has been recorded. To determine whether the phytoplasmas or RLO associated with SLY disease are limited to the strawberry growing districts, diseased plant host species were also collected $50-200 \mathrm{~km}$ from any strawberry farm.

\section{Methods}

\section{Source and location of samples}

Diseased and asymptomatic plants were collected on, or within, $50-100 \mathrm{~m}$ of strawberry runner beds in the Nambour and Stanthorpe districts of south-east Queensland, between March 2001 and January 2003 (Table 1). Diseased plants were also collected in Allora, Gatton, Toowoomba and Warwick districts of south-east Queensland, which are located $50-200 \mathrm{~km}$ from any strawberry farm (Table 1). A single collection was made from Adelaide in South Australia (Table 1).

\section{Screening for phytoplasmas and rickettsia-like-organisms}

Total DNA was extracted from plant samples according to Doyle and Doyle (1990) using a modified CTAB buffer (Padovan et al. 1995). Deoxyribonucleic acid quality was determined by subjecting the samples to electrophoresis in a $1 \%$ agarose gel, which was then stained with ethidium bromide and viewed by UV trans-illumination.

Plant samples were screened for phytoplasmas using the primer pairs fP1/rP7 (Deng and Hiruki 1991; Schneider et al. 1995) and fU5 / m23sr (Lorenz et al. 1995; Padovan et al. 1995), which amplify the phytoplasma $16 \mathrm{~S}$ rRNA gene and $16 \mathrm{~S}-23 \mathrm{~S}$ spacer region. The PCR reactions were prepared according to Schneider et al. (1997) and subjected to 35 cycles of $95^{\circ} \mathrm{C} / 1 \mathrm{~min} ; 55^{\circ} \mathrm{C} / 1 \mathrm{~min}$ and $72^{\circ} \mathrm{C} / 1.5 \mathrm{~min}$. One microlitre of undiluted DNA or DNA diluted $1: 10$ or $1: 50$ in water was used as DNA template in PCR.

Symptomatic and asymptomatic samples were also screened using the fTufAy and rTufAy primers according to Schneider et al. (1997). These primers amplify the Tu elongation factor (tuf) gene of phytoplasmas assigned to the aster yellows and stolbur groups, which includes $\mathrm{Ca}$. P. australiense but not the TBB phytoplasma.

Deoxyribonucleic acid samples were also tested using the PCR primers that amplify the flavoprotein subunit of succinate dehydrogenase $(s d h A)$ gene (PBTF1 and PBTR1) of the RLO associated with lethal yellows (Streten et al. 2005b) and PBT disease (Davis et al. 1998). PCR reactions were prepared according to Davis et al. (1998). Amplification conditions used for the PBTF1 and PBTR 1 primers were $94^{\circ} \mathrm{C} / 1 \mathrm{~min}$, $52^{\circ} \mathrm{C} / 1.5 \mathrm{~min}$ and $72^{\circ} \mathrm{C} / 1 \mathrm{~min}$ for 40 cycles.

\section{Identification of phytoplasmas and rickettsia-like-organisms}

PCR products amplified from diseased and asymptomatic plants using primers specific for the phytoplasma 16S rRNA gene or the RLO $s d h A$ gene were digested with the restriction enzymes $A l u \mathrm{I}$ and RsaI. Tuf genes were digested with HpaII and HindIII (Schneider et al. 1997). All digestions were in buffer supplied by the manufacturer, $1 \mathrm{U}$ enzyme (Promega, Sydney, Australia), $5 \mu \mathrm{L}$ of PCR product and sterile distilled water. Reactions were incubated overnight at the specified temperature and subsequently separated in a $12 \%$ polyacrylamide gel. The gels were then stained with ethidium bromide and visualised on a UV trans-illuminator.

\section{Results}

\section{Rickettsia-like-organism detection in plant host species}

The RLO was detected in only one diseased Jacksonia scoparia sample and one diseased Modiola caroliniana sample; both were collected at Stanthorpe (Tables 1 and 3). The $s d h \mathrm{~A}$ gene amplified from these diseased plants all had the same restriction banding patterns as the reference RLO associated with SLY disease (data not shown). 


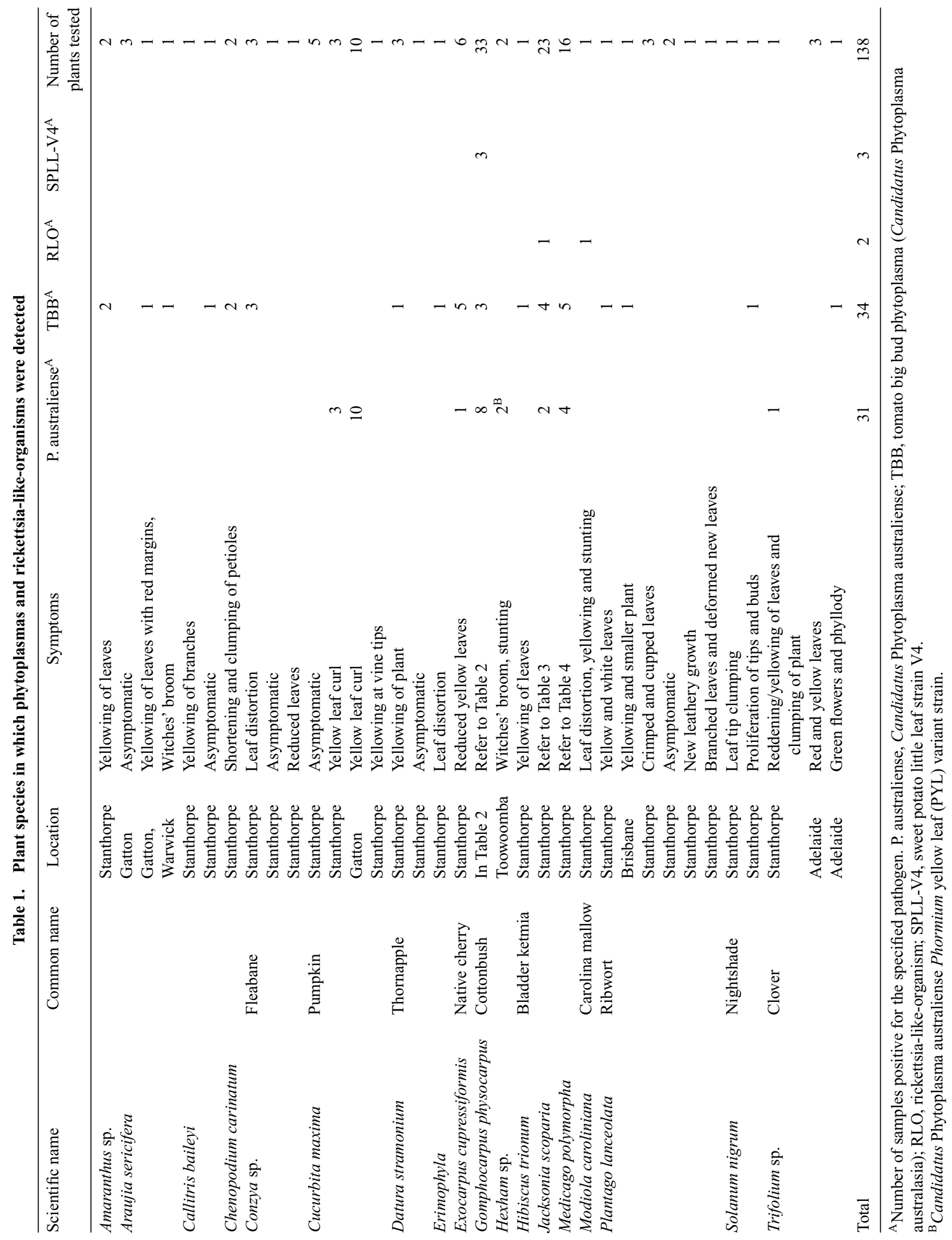




\section{Phytoplasma detection in plant host species}

Eighteen out of 34 diseased plant host species tested positive using phytoplasma specific primers (Tables 1-4). The $\mathrm{Ca}$. P. australiense Australian grapevine yellows (AGY) strain was detected in 25 plants collected from Nambour, Gatton, Stanthorpe and Allora districts of south-east Queensland. The 25 plants represented six different plant species (Tables 1-4). The tuf gene amplified from Hexham sp. (Table 1), and G. physocarpus from Toowoomba and Nambour (Table 2 and Fig. 1) had the same RFLP banding pattern as the Phormium yellow leaf phytoplasma when digested with HpaII and a different banding pattern when digested with HindIII (data not shown). This phytoplasma was designated $C a$. P. australiense PYL variant strain.

The TBB phytoplasma was detected in 33 plants from Stanthorpe, Brisbane, Warwick and Nambour (Tables 1-4) in Queensland and in one plant from Adelaide, South
Australia (Table 1). These 34 diseased samples represented 15 plant species, some of which are also hosts for $C a$. P. australiense. A $C a$. P. australiense and the TBB phytoplasma mixed 'infection', was detected in only one G. physocarpus plant. The SPLL-V4 phytoplasma was detected in single $G$. physocarpus plants from Allora and Nambour (Table 2).

\section{Association between phytoplasma, rickettsia-like- organism and disease}

All pumpkin (Cucurbita maxima) plants exhibiting yellow leaf curl were positive for $C a$. P. australiense AGY strain and all asymptomatic pumpkin plants were phytoplasma negative (Table 1). All native cherry (E. cupressiformis) samples with small leaf symptoms were phytoplasma positive (Table 1).

Ca. P. australiense PYL variant strain was detected in all four $G$. physocarpus plants with yellowing and little leaf or

Table 2. Phytoplasmas detected in Gomphocarpus physocarpus (balloon cottonbush)

\begin{tabular}{|c|c|c|c|c|c|}
\hline Location & Symptoms & P. australiense $\mathrm{e}^{\mathrm{A}}$ & $\mathrm{TBB}^{\mathrm{A}}$ & SPLL-V4A & $\begin{array}{c}\text { Total number } \\
\text { of plants tested }\end{array}$ \\
\hline \multirow[t]{3}{*}{ Allora } & $\begin{array}{l}\text { Yellowing, little leaf, } \\
\text { bunching along stem }\end{array}$ & & & 2 & 2 \\
\hline & Asymptomatic & & & 1 & 1 \\
\hline & Witches' broom & 1 & & & 1 \\
\hline Gatton & Narrow red and yellow leaves & 1 & & & 1 \\
\hline \multirow[t]{8}{*}{ Nambour } & Asymptomatic & 1 & & & 4 \\
\hline & $\begin{array}{l}\text { Reddening and yellows of } \\
\text { stems and leaves }\end{array}$ & & & & 2 \\
\hline & $\begin{array}{l}\text { Little leaf, proliferation of } \\
\text { leaves at terminal ends of } \\
\text { branches and yellowing }\end{array}$ & 1 & 1 & & 1 \\
\hline & Yellow mottling on leaves & & 1 & & 3 \\
\hline & Yellowing and leaf distortion & & & & 5 \\
\hline & $\begin{array}{l}\text { Clumping of leaves along stem } \\
\text { and yellow reduced leaves }\end{array}$ & $1^{\mathrm{B}}$ & & & 1 \\
\hline & $\begin{array}{l}\text { Small mottled leaves clumped } \\
\text { along stem }\end{array}$ & & & & 2 \\
\hline & $\begin{array}{l}\text { Older leaves with yellow } \\
\text { mottling, young leaves } \\
\text { reduced and yellow, curling } \\
\text { of leaves, green petals on } \\
\text { very reduced flowers, leaves } \\
\text { clumping at terminal } \\
\text { ends and leaves protruding } \\
\text { from flowers }\end{array}$ & & 1 & & 1 \\
\hline \multirow[t]{2}{*}{ Stanthorpe } & Asymptomatic & & & & 1 \\
\hline & Yellow distorted leaves & & & & 1 \\
\hline \multirow[t]{3}{*}{ Toowoomba } & Asymptomatic & & & & 3 \\
\hline & Yellowing and reduced leaves & $3^{\mathrm{B}}$ & & & 3 \\
\hline & $\begin{array}{l}\text { Green plant with wilted and } \\
\text { distorted terminals }\end{array}$ & & & & 1 \\
\hline Total & & 8 & 3 & 3 & 33 \\
\hline
\end{tabular}

${ }^{\mathrm{A}}$ Number of samples positive for the specified pathogen. Abbreviations as in Table 1.

${ }^{\mathrm{B}}$ Candidatus Phytoplasma australiense Phormium yellow leaf (PYL) variant strain. 
Table 3. Phytoplasmas and RLOs detected in Jacksonia scoparia (Dogwood)

\begin{tabular}{|c|c|c|c|c|c|}
\hline Location & Symptoms & P. australiense $\mathrm{A}^{\mathrm{A}}$ & $\mathrm{TBB}^{\mathrm{A}}$ & $\mathrm{RLO}^{\mathrm{A}}$ & $\begin{array}{l}\text { Total number } \\
\text { of plants tested }\end{array}$ \\
\hline \multirow[t]{6}{*}{ Stanthorpe } & Abnormal growth at tips & & 1 & 1 & 7 \\
\hline & $\begin{array}{l}\text { Abnormal branching and } \\
\text { growth }\end{array}$ & 2 & 1 & & 3 \\
\hline & Asymptomatic & & & & 6 \\
\hline & $\begin{array}{l}\text { Proliferation of growth at } \\
\text { branch ends }\end{array}$ & & 2 & & 4 \\
\hline & Wilting at branch tips & & & & 1 \\
\hline & Witches broom & & & & 3 \\
\hline Total & & 2 & 4 & 1 & 24 \\
\hline
\end{tabular}

${ }^{\mathrm{A}}$ Number of samples positive for the specified pathogen. Abbreviations as in Table 1.

Table 4. Phytoplasmas detected in Medicago polymorpha (Burr trefoil)

\begin{tabular}{|c|c|c|c|c|}
\hline Location & Symptoms & P. australiense ${ }^{\mathrm{A}}$ & $\mathrm{TBB}^{\mathrm{A}}$ & $\begin{array}{l}\text { Total number } \\
\text { of plants tested }\end{array}$ \\
\hline \multirow[t]{7}{*}{ Stanthorpe } & Reduced leaves with reddening & 2 & & 3 \\
\hline & Asymptomatic & 1 & 2 & 5 \\
\hline & Reddening and curling of leaves & & 2 & 2 \\
\hline & Red leaf margins & & & 1 \\
\hline & $\begin{array}{l}\text { Reduced leaves with curling of } \\
\text { leaf margins }\end{array}$ & & & 1 \\
\hline & Yellow and red leaves & 1 & & 3 \\
\hline & $\begin{array}{l}\text { Stunted growth with reduced } \\
\text { leaves }\end{array}$ & & 1 & 1 \\
\hline Total & & 4 & 5 & 16 \\
\hline
\end{tabular}

${ }^{\mathrm{A}}$ Number of samples positive for the specified pathogen. Abbreviations as in Table 1.

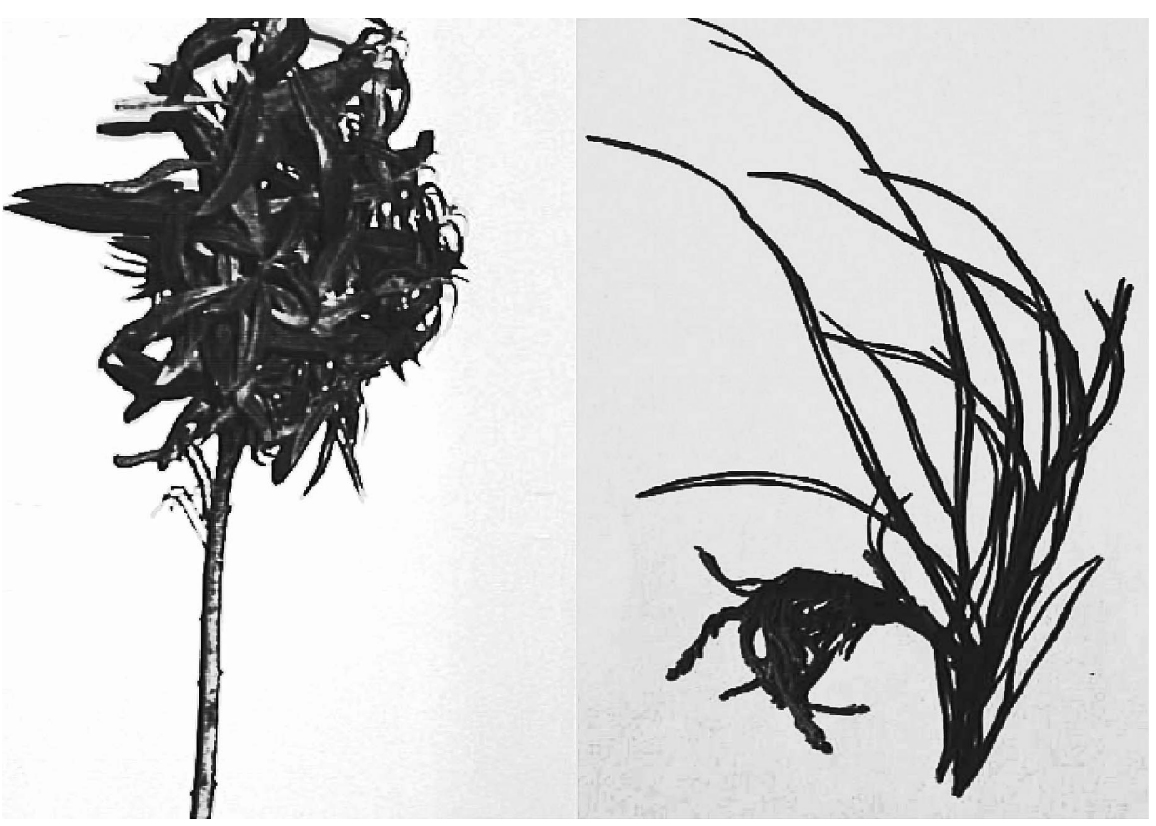

Fig. 1. Gomphocarpus physocarpus infected with Candidatus Phytoplasma australiense Phormium yellow leaf strain (left) and Jacksonia scoparia infected with tomato big bud (TBB) phytoplasma (right). 
clumping of leaves along the stem. G. physocarpus plants with symptoms of yellowing, little leaf and bunching along the stem and also without symptoms tested positive for the SPLL-V4 phytoplasma (Table 2). The TBB phytoplasma was detected in a single $G$. physocarpus plant with symptoms of reduced yellow leaves, green petal and clumping of growth at terminal ends, and in a plant exhibiting yellow mottling of leaves (Table 2). Ca. P. australiense AGY strain and the TBB phytoplasma were detected in one G. physocarpus plant with symptoms of little leaf and proliferation of leaves at terminal ends (Table 4). $\mathrm{Ca}$. P. australiense AGY strain was also detected in G. physocarpus plants exhibiting witches' broom or narrow red/yellow leaves (Table 2). Eleven G. physocarpus plants exhibiting disease symptoms tested negative for phytoplasmas or RLOs (Table 2).

Phytoplasmas were detected more commonly in diseased $J$. scoparia exhibiting an abnormal branching pattern (Fig. 1) than in plants exhibiting other phytoplasmatype symptoms (Tables 1 and 3). An RLO was also detected in $J$. scoparia plants with abnormal branching symptoms (Table 3). M. polymorpha plants with symptoms of reddening and curling of leaves or stunted growth and little leaf tested positive for the TBB phytoplasma (Table 4). Ca. P. australiense AGY strain was amplified from diseased $M$. polymorpha plants with symptoms of reddened reduced leaves or symptoms of yellow and red leaves (Table 4).

Amaranthus sp., Araujia sericifera, Chenopodium carinatum, Erimophyla sp., Hibiscus trionum and Plantago lanceolata were rarely observed with disease so few samples were collected (Table 1). Asymptomatic samples from each of these plant species tested positive for TBB phytoplasma (Table 1). Diseased and asymptomatic Acacia melanoxylon, Acacia sp., Asclepias curassavica, Echinochloa colona, Malva parviflora, Medicago sativa, Osothamnus diosmifolius, Plantago cunninghamii and Sonchus sp. were also sampled during the study (Table 5). No RLO or phytoplasma was detected in these plant species (Table 5).

\section{Discussion}

In Queensland, strawberry growers producing runners are located in the Stanthorpe region while fruit is produced in

Table 5. Plant species in which phytoplasma and rickettsia-like-organisms (RLO) were not detected

\begin{tabular}{|c|c|c|c|c|}
\hline Scientific name & Common name & Location & Symptoms & $\begin{array}{l}\text { Total number of } \\
\text { plants tested }\end{array}$ \\
\hline \multirow[t]{3}{*}{ Acacia melanoxylon } & \multirow[t]{4}{*}{ Blackwood } & \multirow[t]{3}{*}{ Nambour } & $\begin{array}{l}\text { Proliferation of deformed } \\
\text { undifferentiated tissue at buds }\end{array}$ & 1 \\
\hline & & & Asymptomatic & 1 \\
\hline & & & Interveinal yellowing & 1 \\
\hline Acacia sp. & & Stanthorpe & $\begin{array}{l}\text { Yellow young leaves with red } \\
\text { leaf margins }\end{array}$ & 1 \\
\hline Asclepias curassavica & Red Cottonbush & Stanthorpe & Young leaves distorted & 1 \\
\hline \multirow[t]{2}{*}{ Echinochloa colona } & \multirow[t]{2}{*}{ Swamp grass } & \multirow[t]{2}{*}{ Stanthorpe } & White striping on leaves & 1 \\
\hline & & & Asymptomatic & 1 \\
\hline Glycine max & Soybean & Toowoomba & $\begin{array}{l}\text { Proliferation of flowers and seeds. } \\
\text { Yellow seed pods, necrosis of mid } \\
\text { vein, yellowing of leaves }\end{array}$ & 15 \\
\hline \multirow[t]{3}{*}{ Glycine sp. } & & \multirow[t]{3}{*}{ Stanthorpe } & Yellowing leaves & 1 \\
\hline & & & Asymptomatic & 1 \\
\hline & & & Clumping of plant growth & 1 \\
\hline \multirow[t]{2}{*}{ Lycopersicon esculentum } & \multirow[t]{2}{*}{ Tomato } & \multirow[t]{2}{*}{ Stanthorpe } & Asymptomatic & 1 \\
\hline & & & $\begin{array}{l}\text { Reduced leaves, yellowing along } \\
\text { leaf veins }\end{array}$ & 1 \\
\hline Malva parviflora & Marshmallow & Stanthorpe & Yellowing & 1 \\
\hline \multirow{2}{*}{ Medicago sativa } & \multirow[t]{2}{*}{ Lucerne } & \multirow[t]{2}{*}{ Toowoomba } & Asymptomatic & 3 \\
\hline & & & $\begin{array}{l}\text { Shortened internodes, smaller leaves } \\
\text { with clumping and elongation of } \\
\text { leaves and yellowing }\end{array}$ & 2 \\
\hline Melaleuca sp. & Ti tree & Stanthorpe & Chlorotic terminal & 1 \\
\hline Osothamnus diosmifolius & Sago flower & Stanthorpe & Yellowing of leaves & 1 \\
\hline Plantago cunninghamii & Sago weed & Stanthorpe & Yellowing & 1 \\
\hline Plantago sp. & & Stanthorpe & Distorted growth & 1 \\
\hline Solanum mauritianum & Wild tobacco & Stanthorpe & Yellowing of branch tips & 1 \\
\hline Sonchus sp. & Milk thistle & Stanthorpe & Yellowing and reddening of leaves & 2 \\
\hline \multicolumn{2}{|l|}{ Total } & & & 40 \\
\hline
\end{tabular}


the areas surrounding Nambour, Caboolture, Beenleigh and Brisbane. Strawberry plants are not grown all year round, which suggests that non-crop plant species growing near strawberry fields may be reservoirs for phytoplasmas or RLO associated with SLY disease. However, growers remove weeds growing among strawberry plants on fruit production farms and south-east Queensland was experiencing a drought during the study, reducing the number of plant hosts growing on and near strawberry runner and fruit production farms. Therefore, during the survey, the only plant species with symptoms of yellows disease at fruit production farms, where $\mathrm{Ca}$. P. australiense is often detected in SLY or SGP diseased strawberry plants (Padovan et al. 2000b), were Gomphocarpus physocarpus and Acacia melanoxylon. Diseased G. physocarpus were also observed at locations 50-200 km away from fruit production farms.

$C a$. P. australiense AGY strain, $C a$. P. australiense PYL variant strain, TBB and SPLL-V4 phytoplasmas were all detected in diseased G. physocarpus plants, which suggests that these plants are a food source for the insect vectors or this species is susceptible to a range of phytoplasmas. Diseases of Gomphocarpus sp. have also been reported in Italy (D'Aquilio et al. 2002) and the stolbur and European aster yellows phytoplasmas were detected in these plants. Symptomatic G. physocarpus plants were collected at different locations in south-east Queensland, which suggests that these phytoplasmas are not confined to a single location and their insect vectors are distributed throughout south-east Queensland. Based on frequency of phytoplasma detection, the symptoms of green petal, little leaf, and reduced leaves appear to be a phytoplasma disease in G. physocarpus plants. The other symptoms observed for G. physocarpus plants may have been due to nutritional deficiencies, lack of water or another pathogen being present.

In this study, diseased G. physocarpus, M. polymorpha and $J$. scoparia were most frequently observed but other plant species with phytoplasma-type symptoms were also collected. Pumpkin plants with yellow leaf curl were observed at Gatton and $\mathrm{Ca}$. P. australiense AGY strain was detected in these samples, thus confirming this previously reported phytoplasma associated disease (Streten et al. 2005a).

$C a$. P. australiense or the TBB phytoplasma were detected in diseased M. polymorpha, E. cupressiformis, J. scoparia and no mixed phytoplasma 'infections' were detected for these samples. Although $\mathrm{Ca}$. P. australiense and the TBB phytoplasma were identified as having these common host plants, $C a$. P. australiense and TBB are unlikely to have the same vector because they only shared a limited number of host plant species and host range generally reflects the feeding habits of the vector (Lee et al. 2000). Therefore M. polymorpha, E. cupressiformis and J. scoparia are possibly food sources for a range of insect vectors.

The TBB phytoplasma was detected in diseased Amaranthus sp., C. baileyi, C. carinatum, Conzya sp.,
D. stramonium, E. cupressiformis, Erimophyla sp., H. trionum, J. scoparia, M. polymorpha, Plantago lanceolata and $S$. nigrum plants that were located near runner production farms in the Stanthorpe district. Therefore, there is an abundant supply of TBB phytoplasma inoculum in the vicinity of runner production farms. Despite this, the TBB phytoplasma is infrequently detected in plants with SLY disease (Padovan et al. 2000b). The low occurrence of TBB phytoplasma-associated strawberry disease in Stanthorpe where there is a range of sources of inoculum in the surrounding area suggests that the vector, $O$. argentatus, is either not prevalent in the region, or strawberry plants are not a preferred food source for this leafhopper species, or strawberry plants are not highly susceptible to the TBB phytoplasma.

The SPLL-V4 phytoplasma, which is closely related to the TBB phytoplasma (Padovan et al. 2000a), was only detected in diseased G. physocarpus plants collected at Allora. This is in contrast to previous disease surveys in northern Australia, which showed that the SPLL-V4 phytoplasma is associated with diseases that occur in a wide range of plant species (Davis et al. 1997, 2003; Schneider et al. 1999; Padovan and Gibb 2001). The identification of a single plant species positive for the SPLL-V4 phytoplasma compared with the TBB phytoplasma (16 species) suggests that in south-east Queensland, these phytoplasmas may not have a common vector and that the vector for the SPLL-V4 phytoplasma is not prevalent. If the vector for the SPLL-V4 phytoplasma and incidence of the disease is not abundant in south-east Queensland, it is unlikely that strawberry plants will be inoculated with the SPLL-V4 phytoplasma.

The TBB and SPLL-V4 phytoplasmas were detected more frequently in non-crop plants growing in or near Stanthorpe than were the $C a$. P. australiense AGY or PYL variant strains. $\mathrm{Ca}$. P. australiense AGY and PYL variant strains were detected in different $G$. physocarpus plants collected at Nambour and these plants were growing within $100 \mathrm{~m}$ of SLY diseased plants that tested positive for Ca. P. australiense AGY strain (Streten et al. 2005b). $C a$. P. australiense PYL variant strain has previously been identified as being associated with SLY diseased at Caboolture and it was thought that this strain represented an isolated population within Australia (Streten et al. 2005b). The detection of $C a$. P. australiense New Zealand strain at Nambour, Toowoomba and Caboolture in G. physocarpus and Hexham sp. plants showed that this phytoplasma is more widespread than previously thought. These plant species may be reservoirs for this phytoplasma and they may also be a source of inoculum for SLY disease if its vector is present.

The vector of the Australian RLOs is still unknown and this study provided limited insight into the nature of the insect that transmits these organisms. RLO-associated disease was only identified in two non-crop plant hosts in the area surrounding runner production farms where this organism is the most 
common agent associated with SLY disease (Streten et al. 2005b). This suggests that the vector has a limited host range or only a limited number of plants are susceptible to the RLO (Lee et al. 1998; Lee et al. 2000). G. physocarpus plants could not be screened for an RLO because, after PCR amplification, all samples including healthy controls gave a band the same size as the reference RLO strain. We, therefore, do not know if the RLO is associated with this host species.

In conclusion, results from this study suggest that G. physocarpus is a food source for insect vectors of phytoplasmas and, therefore, a possible source of phytoplasma for SLY disease. Diseased pumpkin is also a possible source of $\mathrm{Ca}$. P. australiense for strawberry plants. $\mathrm{Ca}$. P. australiense AGY strain was also detected in diseased $M$. polymorpha plants that were collected on runner production farms and these plants are likely to be a reservoir of phytoplasmas for strawberry plants because they are located in the strawberry growing region and on strawberry farms. Although nine plant species collected on or near runner production farms were positive for the TBB phytoplasma, this may not be significant because this phytoplasma is detected only occasionally in SLY diseased plants. The Australian RLO was detected in diseased M. caroliniana and J. scoparia plants, which were growing on runner production farms in the Stanthorpe district. Thus, these plants may act as reservoirs of the RLO if the insects that feed on these species can acquire and transmit the RLO, and use strawberry as a food source.

This study of phytoplasma and RLO host range, while not intended as a systematic survey of all other host plants in the $200 \mathrm{~km}$ area surrounding commercial strawberry farms, has identified some key non-crop species that are hosts for the RLO and a range of phytoplasmas. Future studies should focus on these species and candidate insect vectors.

\section{Acknowledgements}

This research was supported by the Cooperative Research Centre for Tropical Plant Protection (Brisbane, Australia); and the Better Berries Program, Queensland Department of Primary Industries and Fisheries (Nambour, Australia) led by Mr Neil Greer.

\section{References}

Andersen MT, Beever RE, Sutherland PW, Forster RLS (2001) Association of 'Candidatus Phytoplasma australiense' with sudden decline of cabbage tree in New Zealand. Plant Disease 85, 462-469.

Andersen MT, Longmore J, Liefting LW, Wood GA, Sutherland PW, Beck DL, Forster RLS (1998) Phormium yellow leaf phytoplasma is associated with strawberry lethal yellows disease in New Zealand. Plant Disease 82, 606-609.

Boyce WR, Newhook FJ (1953) Investigations into yellow-leaf disease of Phormium. I. History and symptomatology. New Zealand Journal of Science Technology 34A (supplement 1), 1-11.
D’Aquilio M, Boarino A, Bozzano G, Marzahi C, Roggero P, Boccardo G (2002) First report of phytoplasmas infecting swan plants (Gomphocarpus physocarpus) in Liguria, Italy. Plant Pathology 51, 796. doi: 10.1046/j.1365-3059.2002.00766.x

Davis MJ, Ying Z, Brunner BR, Pantoja A, Ferwerda FH (1998) Rickettsial relative associated with papaya bunchy top disease. Current Microbiology 36, 80-84. doi: 10.1007/s002849900283

Davis RE, Dally EL, Gundersen DE, Lee I-M, Habili N (1997) 'Candidatus Phytoplasma australiense', a new phytoplasma taxon associated with Australian grapevine yellows. International Journal of Systematic Bacteriology 47, 262-269.

Davis RI, Jacobson SC, De La Rue SJ, Tran-Nguyen L, Gunua TG, Rahamma S (2003) Phytoplasma disease surveys in the extreme north of Queensland, Australia, and the island of New Guinea. Australasian Plant Pathology 32, 269-277. doi: 10.1071/AP03020

Davis RI, Schneider B, Gibb KS (1997) Detection and differentiation of phytoplasmas in Australia. Australian Journal of Agricultural Research 48, 535-544. doi: 10.1071/A96114

Deng S, Hiruki C (1991) Amplification of 16S rRNA genes from culturable and non-culturable Mollicutes. Journal of Microbiological Methods 14, 53-61. doi: 10.1016/01677012(91)90007-D

Doyle JJ, Doyle JL (1990) Isolation of plant DNA from fresh tissue. Focus (San Francisco, Calif.) 12, 13-15.

Gibb KS, Persley D, Schneider B, Thomas JE (1996) Phytoplasmas associated with papaya diseases in Australia. Plant Disease 80, $174-178$.

Greber RS, Gowanlock DH (1979) Rickettsia-like and Mycoplasma-like organisms associated with two yellow-type diseases of strawberries in Queensland. Australian Journal of Agricultural Research 30, 1101-1109. doi: 10.1071/AR9791101

Hill AV (1943) Insect transmission and host plants of virescence (big bud of tomato). Journal of the Council for Scientific and Industrial Research Australia 16, 85-90.

Lee I-M, Gunderson-Rindal DE, Bertaccini A (1998) Phytoplasma: ecology and genomic diversity. Phytopathology 88, 1359-1366.

Lee I-M, Davis RE, Gundersen-Rindal DE (2000) Phytoplasmas: Phytopathogenic mollicutes. Annual Review of Microbiology 54, 221-255. doi: 10.1146/annurev.micro.54.1.221

Liefting LW, Beever RE, Winks CJ, Pearson MN, Forster RLS (1997) Planthopper transmission of Phormium yellow leaf phytoplasma. Australasian Plant Pathology 26, 148-154.

Liefting LW, Padovan AC, Gibb KS, Beever RE, Andersen MT, Newcomb RD, Beck DL, Forster RLS (1998) 'Candidatus Phytoplasma australiense' is the phytoplasma associated with Australian grapevine yellows, papaya dieback and Phormium yellow leaf diseases. European Journal of Plant Pathology 104, 619-623. doi: 10.1023/A:1008693904427

Liu B, White DT, Walsh KB, Scott PT (1996) Detection of phytoplasmas in dieback, yellow crinkle and mosaic diseases of papaya using polymerase chain reaction techniques. Australian Journal of Agricultural Research 47, 387-394. doi: 10.1071/AR9960387

Lorenz K-H, Schneider B, Ahrens U, Seemüller E (1995) Detection of the apple proliferation and pear decline phytoplasmas by PCR amplification of ribosomal and nonribosomal DNA. Phytopathology 85, 771-776.

Padovan AC, Firrao G, Schneider B, Gibb KS (2000a) Chromosome mapping of sweet potato little leaf phytoplasma reveals genome heterogeneity within the phytoplasmas. Microbiology 146, 893-902.

Padovan AC, Gibb KS (2001) Epidemiology of phytoplasma diseases in papaya in Northern Australia. Journal of Phytopathology 149, 649-658. doi: 10.1046/j.1439-0434.2001.00688.x 
Padovan AC, Gibb KS, Bertaccini A, Magarey PA, Sears BB (1995) Molecular detection of the Australian grapevine yellows phytoplasma and comparison with grapevine yellows phytoplasma from Italy. Australian Journal of Grape and Wine Research 1, 25-31.

Padovan AC, Gibb KS, Daire X, Boudon-Padieu E (1996) A comparison of the phytoplasma associated with Australian grapevine yellows to other phytoplasmas in grapevine. Vitis 35, 189-194.

Padovan AC, Gibb KS, Persley D (1998) Phytoplasmas associated with diseases in strawberry. Australasian Plant Pathology 27, 280.

Padovan AC, Gibb KS, Persley D (2000b) Association of 'Candidatus Phytoplasma australiense' with green petal and lethal yellows disease in strawberry. Plant Pathology 49, 362-369. doi: 10.1046/j.1365-3059.2000.00461.x

Schneider B, Gibb KS, Padovan AC (1997) Sequence and RFLP analysis of the elongation factor Tu gene used in differentiation and classification of phytoplasmas. Microbiology 143, 3381-3389.

Schneider B, Padovan AC, De La Rue S, Eichner R, Davis R, Bernuetz A, Gibb K (1999) Detection and differentiation of phytoplasmas in Australia: an update. Australian Journal of Agricultural Research 50, 333-342.
Schneider B, Seemüller E, Smart CD, Kirkpatrick BC (1995) Phylogenetic classification of plant pathogenic mycoplasma-like organisms or phytoplasmas. Molecular and Diagnostic Procedures in Mycoplasmology 1, 369-380.

Streten C, Conde B, Herrington M, Moulden J, Gibb K (2005a) Candidatus Phytoplasma australiense is associated with pumpkin yellow leaf curl disease in Queensland, Western Australia and the Northern Territory. Australasian Plant Pathology 34, 103-105.

Streten C, Waite GK, Herrington ME, Hutton DG, Persley DM, Gibb KS (2005b) Rickettsia-like-organisms and phytoplasmas associated with diseases in Australian strawberries. Australasian Plant Pathology 34, 157-164.

White DT, Blackall LL, Scott PT, Walsh KB (1998) Phylogenetic positions of the phytoplasmas associated with dieback, yellow crinkle and mosaic diseases of papaya, and their proposed inclusion in Candidatus Phytoplasma australiense and a new taxon, Candidatus Phytoplasma Australasia. International Journal of Systematic Bacteriology 48, 941-951.

Received 30 July 2004, accepted 25 October 2004 